\title{
Genetic parameter of birth and weaning weights for Friesian calves by using an animal model
}

\begin{abstract}
Birth and weaning weights of 556 Friesian calves by 41 sires out of 318 different dams over a 11 years period were obtained from a herd of Friesian in Sakha Experimental Farm, Ministry of Agriculture, Egypt were used. The records were analyzed by Multiple Trait Likelihood Method (MTDFREML) by using a repeatability animal model (BOLDMAN et al., 1995). Convergence was attained after 699 iterations. The fixed effects included in the model were season and year of calving, parity and sex and the random effects were direct and maternal genetic, permanent maternal environmental and error.

Direct heritability estimates for birth weight (BW) and weaning weight (WW) are 0.28 and 0.13 , respectively, while, maternal heritability estimates for the same traits are 0.14 and 0.06 , respectively. Repeatability estimates are 0.75 and 0.15 for BW and WW, respectively. Phenotypic and genetic correlations are 0.89 and 0.80 , respectively.

Estimates of calve breeding values ranged from -3.12 to $4.11 \mathrm{~kg}$ for BW and ranged from -4.10 to $5.11 \mathrm{~kg}$ for WW. Sire breeding values ranged from -3.40 to $2.99 \mathrm{~kg}$ for BW and ranged from -2.50 to $4.47 \mathrm{~kg}$ for WW. Dam breeding values ranged from -6.80 to $5.54 \mathrm{~kg}$ for BW and ranged from -6.10 to $6.39 \mathrm{~kg}$ for WW.
\end{abstract}

Key Words: genetic, birth weight, weaning weight, animal model, Holstein Friesian, calves

\section{Zusammenfassung}

Titel der Arbeit: Genetische Parameter für Geburts- und Absetzgewichte bei Holstein Friesian Kälbern unter Nutzung eines Tiermodells

Für die Datenanalyse konnten die Geburts-und Absetzgewichte von 556 Friesian Kälbern im Alter von 15 Wochen genutzt werden. Die Kälber stammten von 41 Vätern und 318 Müttern und wurden in der Sakha Versuchsfarm (Ägypten) während eines Zeitraumes von 11 Jahren erfasst. Die Datenanalyse erfolgte mittels der Mehrmerkmals-Likelihoodmethode unter Nutzung eines Tiermodells. Die Heritabilitätsschätzwerte für das Geburtsgewicht und das Absetzgewicht betrugen 0,28 bzw. 0,13. Die maternalen Schätzwerte der gleichen Merkmale lagen bei 0,14 bzw. 0,06, die für die Wiederholbarkeit bei 0,75 bzw. 0,15. Die phänotypischen und genetischen Korrelationen zwischen diesen Merkmalen betrugen 0,89 bzw. 0,80. Es werden die einzelnen Ergebnisse der Zuchtwertschätzung der Kühe, Väter und Mütter vorgestellt und diskutiert. Daraus abgeleitet werden züchterische Schlussfolgerungen einer Einbeziehung dieser Merkmale in das Selektionssystem, bei ausreichenden Töchterzahlen, gezogen.

Schlüsselwörter: Genetische Parameter, Geburtsgewicht, Absetzgewicht, Tiermodell, Holstein Friesian Rinder

\section{Introduction}

Friesian cattle are the most reported dairy cattle in Egypt and they are potential dualpurpose animals, also it contributes about $60 \%$ of red meat production (OUDA, 2001; TAWFIK et al., 2000). The weight of the calf before weaning could be considered as a trait of the mother. The correlations among the phenotypic expressions of weight influence in the different offspring of the same cow are due partially at least to the similarity of the genotypes and to the maternal environment. In addition, birth and weaning weights are the products of beef and dual-purpose cattle sector; therefore the 
results were influenced by the weaning weight. Also, weaning weight is important for cow calf produce because it monitors their primary product (ROBERSON et al., 1986). In addition, the weaning weight expresses the calf rearing ability of cow, so the changes of weaning weight are important factors at selection. Therefore it is an important requirement, to estimate the breeding value based on weaning results very exactly.

Selection of superior cows as bull-sires and bull-dams are a very important part of the breeding program (SWALVE and HÖVER, 2003). Paths sires of bulls and dams of bulls usually contribute about 40 and $30 \%$, respectively of the total genetic gain (REINSCH and KALM, 1995; BRADE and GROENEFELD, 1999; JAGUSIAK and ZARNECKI, 2001). Direct heritability estimates for birth weight and/or weaning weight vary from 0.18 to 0.67 (KEETON et al., 1996; AMIN and GERE, 1997; DODENHOFF et al., 1999; VARONA et al., 1999, KAPS et al., 2000 and LENGYEL et al., 2001; CANTET et al., 2003). Maternal heritability estimates for birth and/or weaning weight ranged from 0.05 to 0.19 (DODENHOFF et al., 1999; VARONA et al., 1999 and DE MATTOS et al., 2000). Repeatability values for birth and/or weaning weights are vary from 0.10 to 0.46 (WILLIS and WILSON, 1974; MOLINA et al., 1999 and BADAWY et al., 2002) or 0.67 (GOYACHE et al., 2003), respectively. Due to different methods, populations, seasons and regions, the heritability and repeatability values vary considerably. In Egypt, till now, selection index procedure and BLUP without relationship coefficients are used to evaluate cow and sire breeding values, because BLUP AM was very expensive and the task of solving mixed model equations (MME) for typical genetic evaluation analysis still require considerable computational effort. The Animal model (AM) is a system for genetic evaluations that estimates breeding values of sires and dams at the same time. In addition, animal models used to analyze maternally influenced trait of beef and dual-purpose cattle (e.g., birth and weaning weights) typically include direct and maternal effects and a permanent environmental effects of the dam (e.g, MEYER, 1992; DODENHOFF et al., 1999).

Therefore, objectives of this study were to estimate genetic parameters associated with direct and maternal genetic effects on birth and weaning weights for Friesian calves in Egypt and to use these estimates in the prediction of breeding values for both traits, by using multivariate analysis (Multi Trait Animal Model).

\section{Material and Methods}

Records on birth and weaning weights of 556 Friesian calves (267 males and 289 females) progeny of 41 sires collected during the period from 1990 to 2000 were used in the present study. The calves were maintained at Sakha Research Station, Kafr ElSheikh Governorate belonging to Animal Production Research Institute, Ministry of Agriculture. The farm located at the Northern Middle part of the Delta. Calves were allowed to suckle their dam's colostrums for the first three days after birth. Thereafter they were artificially reared on natural milk twice daily on the age basis till weaning at the age of $15 \mathrm{wk}$. An amount of $500 \mathrm{~kg}$ of natural milk was available for each calf during the suckling period. Beside milk, green fodder was given to the calves ad libitium according to the schedule applied under the feeding and management system of Animal Production Research Institute (APRI), Egypt. Green fodder in winter was Berseem (Trifolium alexandrinum) and green maize or elephant grass were offered in 
summer. The concentrates (calf meal) and hay were offered to calves from the beginning of the third or fourth week of age according to their age. Calves were weighed for the first time within 24 hours from birth and also at weaning at the age of 15 wk. Weight was recorded before eating or drinking. A calving record considered of calf, sire and dam identity codes, date of calving, sex of the calf, birth date, parity of the dam, birth weight and weaning weight.

Analysis

The records were analyzed by Multiple Trait Derivative Free Restricted Maximum Likelihood (MTDFREML) according to BOLDMAN et al. (1995), using repeatability AM. The Multi Trait Animal Model was used to analyze birth and weaning weights included, direct and maternal genetic, permanent maternal environmental and residual as random effects, season and year of calving, sex and parity as fixed effects. In general, the model for multivariate analysis for two traits is

$$
\left(\begin{array}{l}
Y_{1} \\
Y_{2}
\end{array}\right)=\left(\begin{array}{ll}
X_{1} & 0 \\
0 & X_{2}
\end{array}\right)\left(\begin{array}{l}
b_{1} \\
b_{2}
\end{array}\right)+\left(\begin{array}{ll}
Z_{1} & 0 \\
0 & Z_{2}
\end{array}\right)\left(\begin{array}{l}
u_{1} \\
u_{2}
\end{array}\right)+\left(\begin{array}{ll}
W_{1} & 0 \\
0 & W_{2}
\end{array}\right)\left(\begin{array}{l}
m_{1} \\
m_{2}
\end{array}\right)+\left(\begin{array}{ll}
S_{1} & 0 \\
0 & S_{2}
\end{array}\right)\left(\begin{array}{ll}
p e_{1} & 0 \\
0 & p e_{2}
\end{array}\right)+\left(\begin{array}{l}
e_{1} \\
e_{2}
\end{array}\right)
$$

where:

$Y_{i}=$ vector of observation record for the $i^{\text {th }}$ trait,

$b_{i}=$ vector of fixed effects for the $i^{\text {th }}$ trait (season of calving, two seasons, from

December to May and from June to November; sex of calf; year of calving, from

1990 to 2000 and parity of dams, first and second parity),

$\mathrm{u}_{\mathrm{i}}=$ vector of random animal (direct) genetic effects,

$\mathrm{m}_{\mathrm{i}}=$ vector of random maternal (indirect ) genetic effects,

$\mathrm{pe}_{\mathrm{i}}=$ vector of permanent maternal environmental effects,

$\mathrm{e}_{\mathrm{i}}=$ vector of random residual effects,

$\mathrm{X}_{\mathrm{i}}, \mathrm{Z}_{\mathrm{i}}, \mathrm{W}_{\mathrm{i}}$ and $\mathrm{S}_{\mathrm{i}}$ are incidence matrices relating records of the $\mathrm{i}^{\text {th }}$ trait to fixed, direct genetic, maternal genetic and permanent environmental effects respectively.

It is assumed that

$\operatorname{Var}\left(\begin{array}{l}u_{1} \\ u_{2} \\ m_{1} \\ m_{2} \\ p e_{1} \\ p e_{2} \\ e_{1} \\ e_{2}\end{array}\right)=\left(\begin{array}{llllllll}g_{11} A & g_{12} A & g_{13} A & g_{14} A & 0 & 0 & 0 & 0 \\ g_{21} A & g_{22} A & g_{23} A & g_{24} A & 0 & 0 & 0 & 0 \\ g_{31} A & g_{32} A & g_{33} A & g_{34} A & 0 & 0 & 0 & 0 \\ g_{41} A & g_{42} A & g_{43} A & g_{44} A & 0 & 0 & 0 & 0 \\ 0 & 0 & 0 & 0 & q_{11} & q_{12} & 0 & 0 \\ 0 & 0 & 0 & 0 & q_{21} & q_{22} & 0 & 0 \\ 0 & 0 & 0 & 0 & 0 & 0 & r_{11} & r_{12} \\ 0 & 0 & 0 & 0 & 0 & 0 & r_{21} & r_{22}\end{array}\right) \ldots .(1)$

In equation (1) $g_{i j}$ are elements of $G$ and $g_{i j}$ is the additive genetic covariance between variables $i$ and $j$, where $i=1,2$ refer to direct effects for traits 1,2 and $i=3,4$ refer to maternal effects for traits 1,2 ; $\mathrm{q}_{\mathrm{ij}}$ are elements of $\mathrm{Q}$, the variance and covariance matrix for permanent environmental effects; and $r_{i j}$ are elements of $R$, the variance and 
covariance matrix for residual effects. The Mixed Model Equations (MME) to be solved to obtain the BLUP of $\mathrm{u}, \mathrm{m}$ and pe and BLUE of estimable functions of $\mathrm{b}$.

Estimates of genetic parameters, predicted breeding values for calves, sires and dams were obtained with MTDFREML (BOLDMAN et al., 1995), a set of programs for estimating (co) variance components using animal models and derivative-Free REML (SMITH and GRASER, 1986) The program was restarted with the estimates at previous apparent convergence as initial values until a global minimum of -2 of the log likelihood was found (i.e., when -2logL if the likelihood did not change to the third decimal after consecutive restarts). First, the single trait models were run several times, restating the program with initial values (starting values obtained from OUDA, 2001). Next, for the two trait models, estimates of the effect obtained in the single trait models were used as initial values and were held constant. This results in estimates of covariances between birth and weaning weights. Finally, the estimates obtained in previous steps were used as initial values for a new start allowing all variances and covariances in the model to vary freely during iterations. Convergence was attained after 699 iterations.

\section{Results}

The structure of data considered in the analysis, means, standard deviations (SD) and coefficients of variations (CV\%) for birth and weaning weights are presented in Table 1. Means for birth and weaning weights are $31.84 \pm 4.58 \mathrm{~kg}$ and $97.27 \pm 10.25 \mathrm{~kg}$, respectively. The coefficient of variation for birth and weaning weights are 14.39 and $10.53 \%$ respectively.

Table 1

Data structure used in the analysis, means, standard deviations (SD) and coefficient of variability (CV\%) for birth weight (BW) and weaning weights (WW) for Friesian calves (Datenstruktur, Mittelwerte, Standardabweichung und Variationskoeffizienten für Geburts- und Absetzgewicht der Friesian Kälber)

\begin{tabular}{ccc}
\hline Number & Birth weight & Weaning weight \\
\hline Records & 556 & 556 \\
Sires & 41 & 41 \\
Dams & 318 & 318 \\
ARM & 915 & 915 \\
MME & 4788 & 4788 \\
Means and SD & $31.84 \pm 4.58 \mathrm{~kg}$ & $97.24 \pm 10.25 \mathrm{~kg}$ \\
CV \% & 14.39 & 10.53 \\
\hline
\end{tabular}

ARM, animals in relationship matrix; MME mixed model equations.

Estimation of variance components, heritability (direct and maternal), repeatability of birth and weaning weights and direct genetic, maternal genetic, phenotypic and genetic correlations between the two traits studied are presented in Table 2. Estimates of direct heritability for birth and weaning weights are 0.28 and 0.13 , respectively. Repeatability estimates for birth and weaning weights are 0.75 and 0.15 , respectively (Table 2).

\section{Table 2}

Estimates of parameters and standard errors (in parentheses) for birth weight (BW), kg and weaning weight (WW), kg (Parameterschätzung und Standardfehler für die untersuchten Merkmale)

\begin{tabular}{lcccccccccccc}
\hline Traits & \multicolumn{1}{c}{ Variance and covariance components } & & & $\mathrm{r}_{\mathrm{g}}$ & $\mathrm{r}_{\mathrm{p}}$ \\
& $\sigma_{\mathrm{a}}^{2}$ & $\sigma_{\mathrm{m}}^{2}$ & $\sigma_{\mathrm{am}}$ & $\sigma_{\mathrm{pe}}^{2}$ & $\sigma_{\mathrm{e}}^{2}$ & $\sigma_{\mathrm{p}}^{2}$ & $\mathrm{~h}^{2}$ & $\mathrm{~h}^{2} \mathrm{~m}$ & $\mathrm{t}$ & $\mathrm{r}_{\mathrm{am}}$ & $\mathrm{r}_{\mathrm{g}}$ & \\
\hline BW & 5.146 & 2.54 & 0.570 & 8.47 & 1.47 & 18.19 & $0.28(0.10)$ & $0.14(0.10)$ & $0.75(0.01)$ & $0.16(0.08)$ & $0.80(0.07)$ & $0.89(0.09)$ \\
WW & 12.94 & 5.55 & -03.49 & 1.77 & 79.21 & 95.98 & $0.13(0.09)$ & $0.06(0.09)$ & $0.15(0.01)$ & $-0.41(0.07)$ & & \\
\hline
\end{tabular}


Phenotypic and genetic correlations between birth and weaning weights are 0.89 and 0.80 , respectively (Table 2).

Table 3

Maximum and minimum with standard errors and accuracy of breeding values (BV) from cows, sires and dams for birth and weaning weights (Maximum, Minimum mit Standardfehler und Zuverlässigkeit der Zuchtwerte der Kühe, Väter und Mütter für die untersuchten Merkmale)

\begin{tabular}{lcccc}
\hline BV & Traits & Maximum & Minimum & Accuracy \\
\hline Calves & BW & $4.11(1.03)$ & $-3.12(1.05)$ & 0.21 to 0.67 \\
Calves & WW & $5.11(2.03)$ & $-4.10(2.05)$ & 0.22 to 0.65 \\
\hline Sires & BW & $2.99(1.21)$ & $-3.40(1.86)$ & 0.30 to 0.80 \\
Sires & WW & $4.47(3.00)$ & $-2.50(3.05)$ & 0.30 to 0.80 \\
\hline Dams & BW & $5.54(1.79)$ & $-6.80(2.00)$ & 0.20 to 0.71 \\
Dams & WW & $6.39(2.90)$ & $-6.10(2.90)$ & 0.21 to 0.70 \\
\hline
\end{tabular}

Maximum and minimum values with standard errors and accuracy for calf breeding value (CBV), sire breeding value (SBV) and dam breeding value (DBV) for birth and weaning weights are presented in Table 3.

\section{Discussion}

The present means of birth weight generally fall within the range of those estimates reported in most studies carried out on Friesian calves under Egyptian conditions (Table 1). Birth weight ranged between 25.90 to $37.30 \mathrm{~kg}$ as reported by many authors (ABDEL MOES, 1996 (37.30) and OUDA, 2001 (31.50)). Weight at weaning or at 15 week of age ranged from 76.20 to $98.0 \mathrm{~kg}$ (EL-GAFFARAWY, 1979 (76.20) and OUDA, 2001 (96.60 kg)).

OUDA (2001) using another set of that herd found that CV\% for birth and weaning weights are 13.40 and $9.17 \%$, respectively. The differences between present results and other investigators may be due to differences in the genotypes, management, and number of records and/or methods of analysis.

The present estimates of birth weight in Table 2 are lower than those estimated by MAAROF et al. (1988) (0.43) working on Friesian calves in Egypt. GOYACHE et al. (2003) working at beef cattle found heritability of weaning weight was 0.67 . In this respect, DODENHOFF et al. (1999) working on several breeds of beef cattle, using two single trait animal models, Model 1 included random direct and maternal genetic, permanent maternal environmental and residual environmental effects as well as fixed sex, year and age of dam, while Model 2 included random grand maternal genetic and permanent grand maternal environmental effects, they found that heritability for weaning weight ranged from 0.17 to 0.33 for Model 1 and from 0.11 to 0.33 for Model 2. The present estimates are similar to results obtained by LEE et al. (2000) working on Korean native cattle, found that heritability estimates for weaning weight were 0.13 and 0.07 for direct and maternal effects, respectively, and they concluded that direct and maternal genetic effects and their covariance were previously established as important for birth and weaning weights.

The present estimates are higher than those reported by WILLIS and WILSON (1974), MOLINA et al. (1999) and BADAWY et al. (2002). WILLIS and WILSON (1974) working on Santa Gertrudes calves found that repeatability estimates for birth weight were 0.22 and 0.24 from intraclass correlation and regression of later on earlier records. They concluded that the statistical characteristics of birth weight are a 
maternal trait. In addition, BADAWY et al. (2002) using another set of Friesian calves; found that repeatability for birth and weaning weights are 0.10 and 0.28 , respectively.

STEINHARDT and THIELSCHER (2000) and CANTET et al. (2003) found high correlations between birth and weaning weights in Holstein Friesians and Angus. LENGYEL et al. (2001) working on Simmental calves, found that phenotypic and genetic correlations between birth and weaning weights are 0.90 and 0.89 , respectively; they concluded that the two traits are defined by similar genes.

According to moderate direct heritability for birth weight it can be concluded that the genetic improvement in birth weight can be achieved through selection program. The present estimates of weaning weight is similar to estimate reported by LENGYEL el. al. (2001) working on Simmental beef calves, found that heritability for weaning weight estimates from sire model and AM are 0.096 and 0.11 , respectively. They concluded that the lower heritability estimates could be due to small genetic variance and the effect of sire ranged from 3 to 5\% of the total variance. KEETON et al. (1996) working on Limousin cattle, using single trait sire maternal grandsire model, found that heritability estimates of direct weaning weight and maternal weaning weights were 0.25 and 0.19 , respectively. Also, KAPS et al. (2001) came to the same conclusion on Simmental beef calves. LENGYEL et al. (2001) concluded that the decrease of $h^{2}$ for weaning weight may be due to maternal effect was large influence for weaning weight rather than birth weight. Higher estimate of maternal heritability for birth weight (0.14) than weaning weight (0.06) and positive correlation between maternal and direct genetic effect for birth weight (0.16), indicating that additive maternal genetic effects for birth weight seem to make important contributions to phenotypic variance for birth weight. The present estimates of the genetic correlation between direct and maternal effects for weaning weight (-0.41) are higher than those reported by KOOTS et al. (1994), who reported that the genetic correlation between direct and maternal effects was -0.16. JOHNSON et al. (1992) reported an estimate of -0.36 for this direct-maternal genetic correlation in Angus cattle. MEYER (1992) compared results from different studies of direct-maternal genetic correlation for weaning weight in beef cattle and argued that a less than sufficient environmental may impose a negative correlation. KOCH (1972) suggested that excess milk production by her daughters, also resulting in a negative dam-offspring correlation. He suggested that high weaning weight impede milking potential of the developing animal. MEYER (1997) suggested that inflated estimates of direct-maternal correlations for weaning weight might be caused to some extent by unaccounted-sources of variation. She showed in Hereford cattle that inclusion of the regression on maternal phenotypic for weaning weight in the animal model could explain that part of the direct- maternal covariance us environmental. In addition, the uterine environment and the maternal colostrum may also contribute to the maternal genetic effects. Also, MOLINA et al. (1999) and BADAWY et al. (2002) concluded that the genotype of the calf is more important than maternal influence in determining birth weight. The differences between our estimates and other investigators may be due to attributed to different levels of genetic variation between populations and to the restricted nature and effects of selection data or these differences may be due to computational advances in estimation techniques. 
The higher estimate of repeatability for birth weight in the present study than on weaning weight, indicate that the permanent environmental fractions of variance was high and decrease of permanent environmental until weaning. Therefore, the first calve of each cow would lead to an accurate prediction of future performance, promises efficient selection and also would afford an opportunity for a faster return of sires to service if their evaluation can be made early. In addition, the present results indicate that selection for weights at early weights is a good indication for weights at later ages. In this respect, MOLINA et al. (1999) working on Retinto beef cattle, estimated repeatability for birth and weaning weights by two different methods, intraclass correlation and regression of the second records on the first, found that repeatability for birth weight were 0.134 and 0.296 , respectively, and were 0.356 and 0.458 , respectively for weaning weight. They concluded that the selection on the basis of the first records might be effective in improving the overall performance of the herd in the next year. Also, the same authors concluded that under breeding conditions, transitory environmental effects could be very important. Therefore, it is necessary to correct the birth and weaning weight for the different environmental effects before calculating repeatability. Positive and high phenotypic and genetic correlation between birth and weaning weight indicated that selection for higher birth weight would cause a correlated increase in weaning weight.

Also when Table 3 was investigated, similarly, LENGYEL et al. (2001) found that the expected transmitting ability for weaning weight ranged from -5.79 to $5.86 \mathrm{~kg}$ by using sire model and ranged from -14.77 to $6.92 \mathrm{~kg}$ by using AM. They concluded that the breeding values obtained from sire model and AM was different mainly due to the differences between two methods. On the base of rank of order it appears the breeding values of sires were often overestimated by sire model. On the other hand, GASPARDY et al. (2001) estimated breeding values by the BLUP AM, and found no significant genetic relationships between the breeding values for cows' live weight and breeding values for mothering ability; they concluded that both parameters as two independent selection criteria in the breeding. The same authors concluded also, that the great own weight of terminal of cow is very important beside the good mothering ability. This great own weight results in bigger carcass at slaughter and contribute to large frame of next generation.

The range of CBV' s being $7.23 \mathrm{~kg}$ and $9.21 \mathrm{~kg}$ for $\mathrm{BW}$ and $\mathrm{WW}$, respectively. The range of SBV' s for the same traits were $6.39 \mathrm{~kg}$ and $6.97 \mathrm{~kg}$, respectively. Whereas, the range of DBV' s were $12.34 \mathrm{~kg}$ and $12.25 \mathrm{~kg}$ for BW and WW, respectively. The present results indicate high potential for rapid genetic improvement in birth and weaning weights through selection. In addition, the present results show that predicted breeding values of calves, sires and dams positive values for $\mathrm{BW}$ are also in most cases positive values for WW. These results indicate that selection for BW for the top of calves, sires and dams will increase WW in the next generation and this is a goal of dairymen. From the accuracy point of view, it become clear that the accuracy of sire breeding values (SBV's) ranged from 30 to $80 \%$ which was higher than the accuracy of both $\mathrm{CBV}^{\prime} \mathrm{s}$ (20 to $0.67 \%$ ) and $\mathrm{DBV}^{\prime} \mathrm{s}$ (20 to 70\%). The results showed the important role of sire, these might be due to the large number of daughters per sire. Also, because of the relatively lathe standard errors in the present study large data sets need to be analyzed. In addition, including grand maternal effects in models for genetic analysis for birth and weaning weights seems to be very important. 


\section{References}

ABDEL MOES, K.A.:

Studies on growth performance of Holstein-Friesian calves in a commercial herd. M.Sc., Thesis, Fac. of Agric. Cairo University, (1996)

AMIN, A.A.; GERE, T.:

Body weight at birth of dams and their daughters as a base of heifer's selection under Hungarian conditions. 1. Milk and fat yield improvement. Arch. Tierz., Dummerstorf 40 (1997) 1, 19-24

BADAWY, L.; KASSAB, M.; KHATTAB, A.S.:

Phenotypic and genetic parameters for growth traits in Friesian calves in Egypt. J. Agric. Res. Tanta Univ., 28 (2002), 252-259

BOLDMAN, K.G.; KRIESE, L.A.; VAN VLECK, L.D.; VANTASSELL, C.P.; KACHMAN, S.D.:

A Manual for use of MTDFREML. A set of Programs to obtain estimates of variances and covariances (DRAFT). U.S. Department of Agriculture, Agriculture Research Service, (1995), 114

BRADE, W.; GROENEFELD, E.:

Interaction between sire and dam in dairy cattle breeding. Arch. Tierz., Dummerstorf 42 (1999) 6, 527533

CANTET, R.J.C.; STEIBEL, J.P.; BIRCHMEIER, A.N.; SANTE COLOME, L.F.:

Bayesian estimation of genetic parameters for growth and carcass traits of grass-fed beef cattle by full conjugate gibbs. Arch. Tierz., Dummerstof 46 (2003) 5, 435-443

DODENHOFF, J.; VAN VLECK, L.D.; GREGORY, K.E.:

Estimation of direct maternal and grand maternal genetic effects for weaning weight in several breeds of beef cattle. J. Anim. Sci., 77 (1999), 840-845

DE MATTOS, D.; BERTRAND, J.K.; MISZTAL, I.:

Investigation of genotype $\mathrm{x}$ environmental interactions for weaning weight for Herefords in three Countries. J. Anim. Sci., 78 (2000), 2121-2126

EL-GAFFARAWY, A.A.:

Genetical and some environmental influences affecting growth rate of Friesian calves and crosses up till maturity. M. Sc. Thesis Fac. of Agric. Al - Azhar Univ. Cairo, Egypt, (1979)

GASPARDY, A.; JAVORKA, L.; SZABARA, L.; DOMOKOS, Z.; KOMLOSI, I.:

The importance of the cow's live weight in the terminal line. 52th Annual Meet. European Assoc. for Animal Production, Budapest, Hungary, August 26-29, (2001)

GOYACHE, F.; FERNANDEZ, I.; ROYO, L.J.; ALVATEZ, I., GUTIEREZ, J.P.:

Factors affecting actual weaning weight, preweaning average daily gain and relative growth rate in Asturian de los Valles beef cattle breed. Arch. Tierz., Dummerstorf 46 (2003) 3, 235-243

JAGUSIAK, W.; ZARNECKI, A.:

Genetic level of bull-dam herds. 52th Annual Meet. European Assoc. for Animal Production. Budapest, Hungary, August, 26-29, (2001)

JOHNSON, Z. B., WRIGHT, D.W., BROWN, C. J., BERTRAND, J.K., BROWN, A.H.:

Effect of including relationships in the estimation of genetic parameters of beef calves. J. Anim. Sci., 70 (1992), 78-88

KAPS, M.; HERRING, W.O.; LAMBERSON, W.R.:

Genetic and environmental parameters for traits derived from the body growth curve and their relationships with weaning in Angus cattle. J. Anim. Sci., 78 (2000), 1436-1442

KEETON, L.L.; GREEN, R.D.; GOLDEN, B.L.; ANDERSON, K.J.:

Estimation of variances components and prediction of breeding values for Scrotal Circumference and weaning weight in Limousin cattle. J. Anim. Sci., 74 (1996), 31-36

KOCH, R.M.:

The role of maternal effects in animal breeding: VI. Maternal effects in beef cattle. J. Anim. Sci., 35 (1972), 1316-1323

KOOTS, K.R.; GIBSON, J.P.; WILTON, J.W.:

Analysis of published genetic parameter estimates for beef production traits. I-Phenotypic and genetic correlations. Anim. Breed. Abstr., 62 (1994), 825-844

LEE, J.W.; CHOI, S. B.; JUNG, Y.H.; KEOWN, J.F.; VAN VLECK, L.D.:

Parameter estimates for direct and maternal genetic effects on yearling, eighteen-month, and slaughter weights of Korean native cattle. J. Anim. Sci., 78 (2000), 1414-1421

LENGYEL Z.; SZABO, F.; KOMLOSI, I.:

Effects of year, season, number of calving and sex on weaning performance of Hungarian Simmental beef calves. 52th Annual Meet. European Assoc. for Animal Production. Budapest, Hungary, August 26-29, (2001)

MAAROF, N. M.; MAGID, S. A.; AI-ANI, A. M. S.: 
Studies of body weight of Friesian cattle. II - Some phenotypic and genetic parameters. J. Aric. and MEYER, K.: Water Res. Anim. Prod., 7 (1988), 35-40

Variance components due to direct and maternal effects for growth traits of Australian beef cattle. MEYER, K.: Livest. Prod. Sci., 31 (1992), 179-204

Estimates of genetic parameters for weaning weight of beef cattle accounting for direct-maternal environmental variance. Livest. Prod. Sci., 52 (1997), 187-199

MOLINA, A.; RODERO, A.; RODERO, E.; JIMENEZ, J.M.:

Repeatability of growth in Retinto beef cattle. J. Anim. Breed. Genet., 116 (1999), 61-73

OUDA, E.Z.M.:

Environmental and genetic effects on birth weight, weaning weight and average daily gain in Friesian calves in Egypt. 52th Annual Meet. European Assoc., for Animal Production, Budapest, Hungary, August 26-29, (2001)

REINSCH, N.; KALM, E.:

Gene-flow and relative importance of maternal, paternal and direct effects in dairy cattle (German language). Arch. Tierz., Dummerstorf 38 (1995) 4, 355-366

ROBERSON, R.L.; SANDERS, J.O.; CARTWRIGHT, T.C.:

Direct and maternal genetic effects on preweaning characters of Brahman, Hereford and BrahmanHereford crossbred cattle. J. Anim. Sci., 63 (1986), 438-446

SMITH, S.P; GRASER, H.U.:

Estimating variance components in a class of mixed model by restricted maximum likelihood. J. Dairy Sci., 69 (1986), 1156-1165

STEINHARDT, M.; THIELSCHER, H.-H.:

Growth and development quality of dairy calves reared in groups with an automatic milk feeder. Physiological variables and their changes at specific age periods (German language). Arch. Tierz., Dummerstorf 43 (2000) 1, 27-44

SWALVE, H. H.; HÖVER, K.:

Examination using the results of breeding value estimation for Holstein sires and cows in Germany (German language). Arch. Tierz., Dummerstorf 46 (2003) 2, 113-126

TAWFIK, E.S.; MOHSEN, M.K.; SALEM, A.Y.; EL-AWADY, H.G.:

Study on Friesian herds raised in Egypt and Germany. I. Estimate of non-genetic effects and genetic parameters. Arch. Tierz., Dummerstorf 43 (2000) 6, 101-114

VARONA, I.; MISZTAL, I.; BERTRAND, J.K.:

Threshold-linear versus linear-linear analysis of birth weight and calving ease using an animal model: IVariance component estimation. J. Anim. Sci., 77 (1999), 1994-2002

WILLIS, M.B; WILSON, A.:

Factors affecting birth weight of Santa Gertrudis calves. Anim. Prod., 18 (1974), 231-236

Received: 2004-05-25

Accepted: 2005-04-29

Authors' addresses

Assoc. Prof. Dr. HÜLYA ATIL*

Faculty of Agriculture, Ege University

Bornova, 35100,

Izmir, Turkey

Prof. Dr. ADEL SALAH KHATTAB

Faculty of Agriculture, Tanta University,

Tanta, Egypt

LILA BADAWY

Ministry of Agriculture, Animal Production Department

Egypt

*Corresponding author

E-Mail: atil@ziraat.ege.edu.tr 